DOI: $10.22616 /$ REEP.2019.034

\title{
A Multi-Aspect View on the Purposefulness of University Students as Prospective Teachers
}

\author{
Inese Jurgena ${ }^{1}$ Dr. paed.; Dagnija Cedere ${ }^{2}$ Dr. chem.; Irena Katane ${ }^{3}$ Dr. paed. \\ University of Latvia ${ }^{1 ; 2}$; Latvia University of Life Sciences and Technologies ${ }^{3}$, Latvia \\ inese.jurgena@lu.lv¹; dagnija.cedere@lu.lv²; irena.katane@llu.lv³
}

\begin{abstract}
Securing the quality and purposefulness competitiveness of education is one of the most topical issues in contemporary society. It can be achieved if there are competent and competitive teachers. The contemporary society requires that every individual, including prospective teachers, use their abilities, knowledge and skills, be persistent, be able to work and achieve their goals under the conditions of high levels of stress and the changing environment, act prudently and maintain purposefulness in their life activity. The present article constitutes a multi-aspect theoretical and empirical study, analysis and evaluation of the purposefulness of university students - prospective teachers with regard to: 1) the direction of personality, including the needs and motives of activity; 2) teachers' preparedness for professional activity; 3) the competitiveness of specialists, including teachers, in the areas where experience is the basis for competitiveness, 4) as well as self-directed learning and career self-management. The aim of the article is to present the results of theoretical and empirical research, evaluating the purposefulness of students - prospective teachers from various aspects. The empirical research was based on the methods of survey and experience reflection. There was used a survey questionnaire. The survey sample included 108 first-year and second-year students of the University of Latvia enrolled in different teacher education programmes. During data processing the obtained results are statistically significant. Results show that prospective teachers need knowledge on promoting purposefulness to be able to choose their life goals and be aware of the possibilities to achieve them. The formation of purposefulness in the process of studies is one of the key opportunities that develop students' self-regulation skills and promote the development of self-confidence and selfesteem. Regarding the formation of purposefulness, it is very important for prospective students to perceive studies as a process personally significant for them. In such a way, they develop their selfexperience where learning becomes personally relevant for them. The results of the research show that most students do not regard the studies as a process personally significant for them.
\end{abstract}

Keywords: purposefulness, prospective teachers, career self-management, self-actualization, university education.

\section{Introduction}

"Latvia 2030 - Sustainable Development Strategy of Latvia" emphasizes that education is one of the most important factors ensuring Latvia's economic growth, competitiveness and sustainable development (Sustainable Development Strategy..., 2010).

The need for a conceptually new teacher-training system is highlighted in the most authoritative OECD report on the quality of education in in the world (Education at a Glance..., 2018). Several major projects funded by ESF are implemented in Latvia aimed at radically changing the standards and approaches to the content of general education until 2023, as well as restructuring teacher-training programmes. It is envisaged that the motivation of candidates and their suitability for the work in educational institutions will be assessed when enrolling potential students for teacher-training programmes at the institutions of higher education (National Reform Programme..., 2018, 51).

In the period since Latvia regained its independence, significant reforms have been carried out in the system of education. One of the strategic objectives for the development of higher education is enhancing its quality and competitiveness.

The competitiveness of education is not possible without the competitiveness of competent teachers. Therefore, when educating prospective teachers, particular attention must be paid to the development of teachers' competitiveness, i.e., the development of their purposefulness since the purposefulness of a teacher as a personality and specialist is one of the key indicators of competitiveness. 
The sustainability of contemporary education largely depends on the extent to which it meets the needs of society. The society requires that every individual be able to use their abilities, knowledge and skills, be persistent, be able to work and achieve their goals under the conditions of high levels of stress and the changing environment, act prudently and maintain purposefulness in their life activities.

The topicality of facilitating the development of purposefulness of young and prospective teachers in the process of higher education is also underpinned by the issue concerning the inclusion of teachers as specialists in the labour market in the current economic conditions because not all young specialists are able to evaluate their professionalism adequately and fit into their work-place, i.e., a school or pre-school environment. Therefore, teacher mobility, the flexibility of thinking and actions as well as the ability to actualize themselves in the changing environment have a significant impact on their purposefulness, and vice versa - to be able to meet challenges in the educational environment, including the undergoing reforms, and actualize themselves as professionals, teachers need clear life goals and professional goals. An important factor related to the awareness and achieving of these goals is the professional identity of prospective and young teachers, i.e., whether a young specialist identifies himself/herself with the chosen profession and intends to connect his/her career with the teaching profession.

Purposefulness in one's career self-management also indicates the extent to which a prospective teacher is ready for independent professional activity and the subsequent life-long professional selfdevelopment.

The aim of the article is to present the results of theoretical and empirical research, evaluating the purposefulness of students - prospective teachers from various aspects.

\section{Methodology}

In order to substantiate and evaluate the purposefulness of prospective teachers and the topicality of facilitating it at the institutions of higher education from a multi-aspect perspective, there was conducted both theoretical research and an empirical study.

The theoretical research was conducted in various directions:

- Goals as an integral part of the structure of personality direction and one of the sources of motivation, but personality direction as a personality core (Covington, 1992; Gokce, 2010; Kalnina, Katane, 2010; Leontiev, 1978/2000; Nuttin, Lens, 1984; Rubinstein, 1989/2004; Schunk, Pajares, 2009);

- Personality needs as the precondition for purposefulness (Bandura, 1977; Bandura, 1986; Maslow, 1954; Nuttin, Lens, 1984; White, 1959; Winch, Foreman-Peck, 2000);

- Purposefulness as the indicator of competitiveness, including demandability and employability, whereas experience is the basis of competitiveness (Asonitou, 2015; Boholano et al., 2016; Bogoyavlenskaya, Kliueva, 2013; Kalnina, Katane, 2010; Katane, 2010; Katane, 2011a; Katane, 2011b; Katane, Baltusite, Katans, 2017; Shirobokov, Roe, 2005);

- Purposefulness as the indicator of teacher's psychological preparedness for independent professional activity (Baltusite, 2013; Baltusite, Katane, 2014; Strode, 2010; Wang et al., 2018);

- Purposefulness as a precondition for and the result of continuous education, self-directed learning, life-long professional self-development and self-determination, as well as career selfmanagement (Baltusite, Katane, 2017; Bary, Rees, 2006; Iriste, Katane, 2016; Katane, Baltusite, Katans, 2017; Paradnike, Endriulaitiene, Bandzeviciene, 2016; Strods, 2006; Strods, 2012).

The evaluation of the purposefulness of prospective teachers was based on scientific research methodology (Laing, Todd, 2015; Walsh, Sattes, 2016).

Research methods. The theoretical research involved the study, analysis and evaluation of scientific literature, including various kinds of regulatory documents concerning the purposefulness of young or prospective specialists, including teachers, from various perspectives and in various contexts.

The empirical study was based on the methods of survey and experience reflection. There was used a survey questionnaire with closed questions according to a 5-point Likert scale with responses ranging from 1 - strongly disagree to 5 - strongly agree. The reliability (inter-item consistency) of the questionnaire according to Cronbach alpha was 0.91 . 
The data processing was performed by means of several methods of mathematical statistics to obtain both descriptive statistics and statistical conclusions (Mann-Whitney U test, Kruskal Wallis Test, Spearman's rank correlation test) using SPSS software.

The survey sample included 108 first-year and second-year students of the University of Latvia enrolled in different teacher education programmes, including the training of pre-school teachers $(68 \%)$, elementary school teachers $(17 \%)$, the prospective managers of education institutions $(10 \%)$ and others $(5 \%)$. There were $87(80.6 \%)$ part-time students and $21(19.4 \%)$ full-time student among the respondents, with 107 females and 1 male among them. The average age of the respondents was 31.2. The survey was conducted in 2018.

The present article contains part of the theoretical and empirical results of the study.

\section{Results and Discussion}

\section{Results of Theoretical Research and Discussion}

The link between purposefulness and motivation is highlighted in studies concerning the life goals of youth and their notions of expected results, professional interests and career development goals, youth purposefulness, work in the leisure time, educational achievements and career development (Bernande, 2013; Caughlin, 2010; Jurgena, Gedrovics, 2011; Jurgena, Gedrovics, Cedere, 2014; Kalnina, Katane, 2010; Kardeliene, 2016; Lamanauskas, Augiene, 2017).

The factors concerning the purposefulness of prospective teachers - the need to achieve their goals, the awareness and setting of goals, choosing means to achieve one's goals, using the means appropriate to a particular situation, making specific plans for future life activities and taking specific pro-active action in order to implement the goals - are associated with the awareness of one's possibilities and achievements and their adequate assessment (Bernande, 2013).

Students' life activities at the institution of higher education and their pedagogic management are objective factors promoting purposefulness and personal achievements, as well as the development of such personal qualities as independence, responsibility, initiative and creativity.

The awareness of one's goals promotes the development of personality provided the goal becomes a motive for student's activity. Therefore, it is necessary to pay attention not only to the objective meaning of the goal, but also to its subjective sense.

The methodological foundation of the study comprises: ideas about individual's activity and the meaning of life activities (Leontiev, 1978/2000; Rubinstein, 1989/2004), goal theory (Leontiev, 1978/2000; Locke, Latham, 1991; May, 1989; Rubinstein, 1989/2004; Vallerand, 1997; Weiner, 1996) and attitude theory (Leontiev, 1978/2000).

Within the framework of our study, it is important to understand that achieving goals and purposeful behaviour are very important for the development of learning motivation (Locke, Latham, 1991). The theory of academic motivation proposed by R.J. Vallerand (Vallerand, 1997) reveals the essence of amotivation, or no-motivation, which means that a student is unable to explain the motives of his/her activity, or these motives are vague and diffusive. B. Weiner (Weiner, 1996; Weiner, 2000), the author of attribution theory, also expressed an important idea that most students tend to explain their failures attributively, paying more attention to outer circumstances than to their self-actualization.

Regarding the promoton of the development of student purposefulness, the idea proposed by S.L. Rubinstein (1989/2004) about the interconnection of will and the goal and the progression form external to internal control is also important. Will does not stem directly from needs, but from the awareness of motives and their result - the goal. The goal itself is the dominant stimulus. The regulation of activity by means of will is conscious and mediated by goals and motives. Therefore, purposefulness is defined as the most important volitional feature of personality that manifests itself in the ability to set and achieve goals. From the perspective of life activities, the goal can be analysed as a structural component of activity, as the component of meaning and the component of life activity. The most important aspect regarding the definition of the goal is the idea of a goal as a deliberate motive and task. The goal of activity is the interconnection between a subjective need and the notion of what is necessary to meet this need 
(Rubinstein, 1989/2004), the mentally predicted/envisaged desirable or achievable result; the goal expresses the meaning of any activity and characterises the content of human life (May, 1989).

Purposefulness is defined as the most important characteristic of individual's will which manifests itself in the ability to set and achieve goals. A purposeful individual can understand and analyse the sphere of his/her motivation and needs independently and profoundly and match his/her desires to the knowledge, skills, abilities and possibilities (Bernande, 2013).

The development of youth determination involves three stages of self-regulation: the choice of goals, the stimulus to take action in order to reach the desirable goal and monitoring one's progress towards achieving the goal (Meissner, 2009).

The factors promoting individual's purposefulness both in education and in other areas of life activity can be diverse: individual's ability to understand and set the goal, which is related to initiative, selfregulation, which is associated with undertaking responsibility for one's actions and is secured by adequate self-confidence (Bandura, 1977; Bandura, 1986, Rubinstein, 1989/2004), the use of appropriate means for achieving one's goals (Yeager, Bundick, 2009).

It should be noted that teacher's assistance is an essential factor in developing students' awareness of their goals and goal-setting skills (Vallerand, 1997), as well as the interconnection between purposefulness and motivation, which is shown by studies concerning the life goals of the youth and their notions about expected results and career development goals (Hirschi, 2010; Jurgena, Gedrovics, 2011). On the other hand, motivation as a factor promoting purposefulness is closely linked with attitudes. Attitudes manifest themselves and develop in the process of satisfying needs and activities aimed at achieving goals in accordance with the possibilities in particular social conditions. Attitudes manifest themselves in individual's actions and behaviour (Bernande, 2013).

The analysis of the theoretical literature led to the conclusion that regarding the development of purposefulness it is important to evaluate the abilities of prospective teachers to be aware of the goal of their activities, to set goals and choose the means for achieving them, to use these means appropriately and to stimulate the need to achieve the goals.

In the process of studies, the activities of teachers and students are associated with direct and reflexive relationships that manifest themselves in their active inter-connection. This inter-connection is underpinned by common goals: to teach and to learn. If a student possesses the aforementioned components that promote purposefulness: the meaning of life, attitudes, will, needs, motivation and the goal, it can be assumed that there will be a purposeful process of learning, and purposefulness will be promoted in this process (Bernande, 2013).

The process of studies as student's cognitive activity promotes not only their intellectual, emotional, volitional and physical development and the cognition of the diversity of reality, but also forms various social values and creates the experience of self-cognition and self-actualization (Lamanauskas, Augiene, 2017). Educational and personal success are criteria promoting purposefulness.

According to statistics (Statistika par augstako..., 2018), in the academic year 2017/2018, 19350 students started their studies at the institutions of higher education (universities and colleges in Latvia), but only 14587 completed them. A question arises: What are the reasons behind the decision of so many students to renounce their choice, i.e. the goal to become specialists in a certain profession? One of the answers is the following: there is a contradiction between the strivings of prospective teachers to attain their goals, on the one hand, and the satisfaction with the achieved results, on the other hand. As a result, young people cannot achieve the goals they have set, and they lose motivation.

Purposefulness lies at the basis of individual's life activities and ensures achievements in educational institutions, outside them and in subsequent life activities. The development of purposefulness is underpinned by the goal of life activities, the function of which is individual's plan of his/her life path and its implementation.

\section{Results of Empirical Research and Discussion}

The results of the survey show the understanding of the goal in prospective teachers enrolled in different teacher training programmes as well as their readiness for purposeful activity, their evaluation of the studies at the institution of higher education and the possibilities to achieve the goals they have set. The 
study does not show significant differences between the purposefulness of first-year and second-year students. The responses of the students enrolled in different teacher-training programmes are also similar. Looking at the mean values of the responses, it can be inferred that prospective teachers are responsible and independent; they are aware of their goals and are able to set them, to choose appropriate means for achieving these goals and apply them. This is indicated by comparatively high mean values of the responses $(\mathrm{M}=3.52$ - 4.68), which correspond to the dominant responses "agree" and "strongly agree" in the 5-point scale. Both first-year and second-year students, regardless of the form of studies, regard the awareness of their goals and needs as high $(\mathrm{M}=4.21, \mathrm{SD}=0.68$ and $\mathrm{M}=4.29, \mathrm{SD}=0.71$ respectively).

There can be observed a slight difference between the views of full-time and part-time students. Due to having little study experience, the respondents evaluate their academic success cautiously; at the same time, they regard institutions of higher education as very important for them (C3); $M=4.38$ and 4.44 (Figure 1).

As the results of the survey do not correspond to the normal distribution, Mann-Whitney U test was used to compare both independent groups. Mann-Whitney $U$ test made it possible to single out one statistically significant difference in the views of full-time students (FT) and part-time students (PT) - the part-time students are better aware of their goals than the full-time students $\left(\mathrm{M}_{\mathrm{FT}}=3.62, \mathrm{M}_{\mathrm{PT}}=4.08, \mathrm{Z}=-2.4, \mathrm{p}=\right.$ 0.02). We believe that the results of the study could be explained by the actualization of adult selfexperience. Self-experience refers to the knowledge, skills and attitudes obtained, experienced and evaluated in life activity that have transformed into personally significant values (Brigmane, 2014). As most of the part-time students are already involved in pedagogical work, their primary experience is richer.

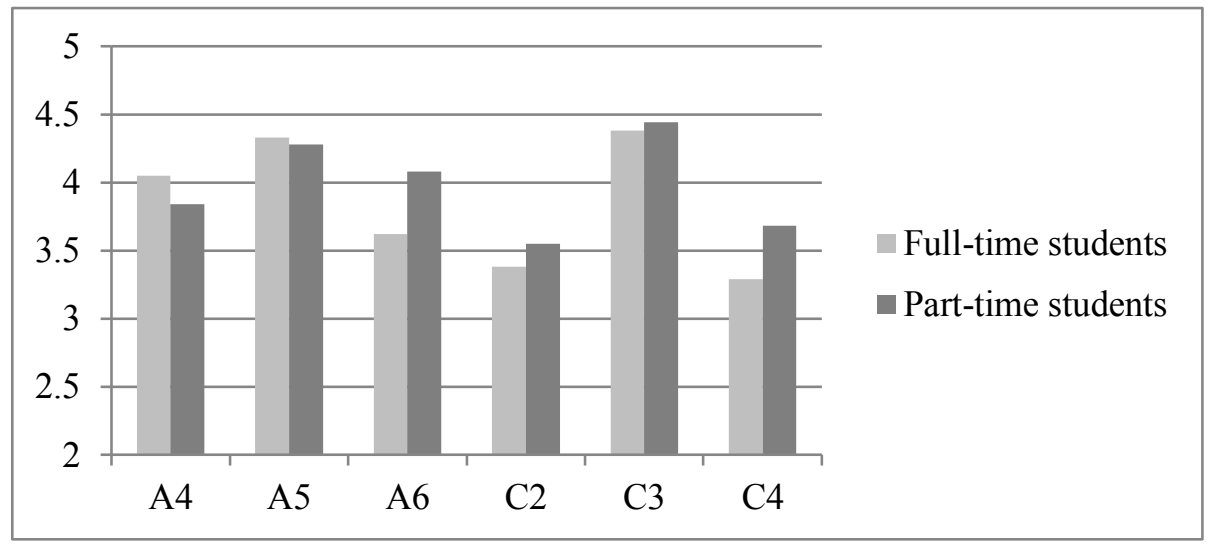

Abbreviations:

A4 - ability to use means for achieving goals;

A5 - need to achieve the goal;

A6 - clarity of one's goals;

$\mathrm{C} 2$ - originality, uniqueness of academic achievement;

C3 - personal significance of academic achievement;

$\mathrm{C} 4$ - significance of academic achievement for other people.

Figure 1. Factors characterising the purposefulness of full-time and part-time students (the mean values of the responses $1 \leq \mathrm{M} \leq 5$ ).

The next aspect of the study was respondents' views concerning the choice of various means to succeed at the institution of higher education and how they correspond to the relatively high indicators of student purposefulness. According to the respondents, the key factors leading to success in their studies are knowledge, skills and experience $(\mathrm{M}=4.68, \mathrm{SD}=0.53)$, the ability to analyse and draw conclusions $(\mathrm{M}=4.43, \mathrm{SD}=0.60)$ and the invested effort $(\mathrm{M}=4.44, \mathrm{SD}=0.78)$. The students attach less importance to various connections and friends $(\mathrm{M}=3.99, \mathrm{SD}=0.86)$. 
Table 1

The correlation between the choice of means to attain academic success and the self-assessment of purposefulness (Spearman's rank correlation coefficients $r_{s}$ )

\begin{tabular}{|c|c|c|c|c|c|c|c|}
\hline $\begin{array}{l}\begin{array}{r}\text { Self-assessment of } \\
\text { purposefulness } \\
\text { (factors A) }\end{array} \\
\text { Means to attain } \\
\text { academic success at the } \\
\text { institution } \\
\text { of higher education } \\
\text { (factors F) }\end{array}$ & 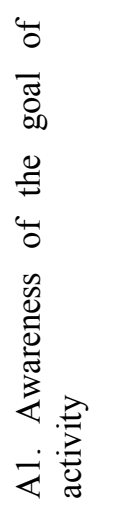 & 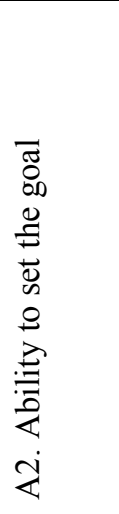 & 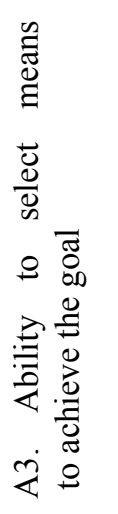 & 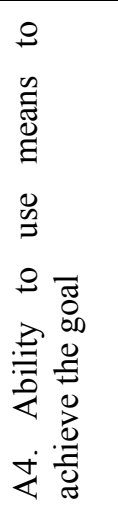 & 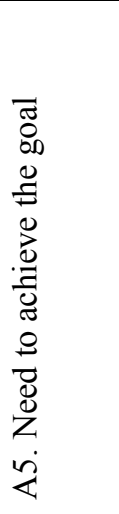 & 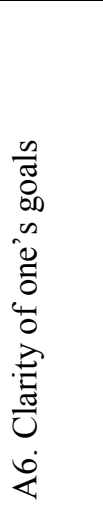 & 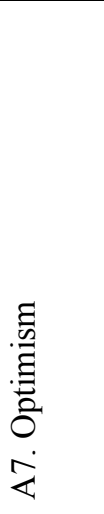 \\
\hline F1. Effort & $0.28^{* *}$ & 0.15 & $0.20^{*}$ & 0.17 & $0.22^{*}$ & $0.20^{*}$ & 0.04 \\
\hline $\begin{array}{l}\text { F2. Knowledge, skills, } \\
\text { experience }\end{array}$ & 0.10 & 0.04 & 0.10 & 0.00 & 0.14 & 0.10 & 0.12 \\
\hline F3. Connections, friends & 0.13 & 0.17 & $0.27^{* *}$ & $0.31^{* *}$ & 0.17 & $0.24^{*}$ & 0.13 \\
\hline F4. Ability to set goals & $0.40^{* *}$ & $0.43^{* *}$ & $0.32^{* *}$ & $0.30^{* *}$ & $0.34^{* *}$ & 0.18 & $0.24^{*}$ \\
\hline $\begin{array}{l}\text { F5. Ability to analyse, } \\
\text { conclude and plan }\end{array}$ & $0.36^{* *}$ & $0.41^{* *}$ & $0.28^{* *}$ & $0.28^{* *}$ & $0.38^{* *}$ & 0.15 & $0.28^{* *}$ \\
\hline F6. Potentialities, talents & $0.19^{*}$ & $0.29^{* *}$ & 0.04 & 0.16 & 0.17 & -0.01 & 0.16 \\
\hline
\end{tabular}

**. Correlation is significant at the 0.01 level.

*. Correlation is significant at the 0.05 level.

The data were processed by means of Spearman's rank correlation test, and the obtained results show a strong correlation between the awareness of the goal of activity (A1), the ability to set the goal (F4), $r_{s}=0.40$, and the ability to analyse and draw conclusions (F5), $r_{s}=0.36$ (Table 1). However, there is no significant correlation between factors A1 - A7, which characterise purposefulness, and factor F2 (knowledge, skills and experience). This fact implies significant differences in respondents' views, showing that not all the respondents see the connection between achieving the goal and knowledge, skills and experience as the means for achieving this goal. There is weak correlation between factors A1 - A7 and effort as the means to attain academic success at the institution of higher education (F1). The students see the role of their individual potentialities and talents (F6) only regarding the ability to set the goal, where a weak correlation can be observed.

The obtained results demonstrate the diversity of students' views. Therefore, in the following stage of the study, all the respondents were divided into numerically similar groups according to their age: group A - under the age of $25(n=35)$, group B - ages 26-34 $(n=35)$ and group $C$ - over the age of 35 $(n=38)$. The intention was to clarify how the awareness of the goal and the ways of achieving it correlates with life experience. As a result of the correlation analysis by groups, it was found that the correlation between the need to achieve the goal and the effort to be invested in achieving this goal was more strongly expressed in the younger participants of the survey (group A): $r_{s}=0.41, p=0.01$ compared to groups B and C. On the other hand, in the respondents with bigger life experience (groups B and C), the effort invested in the studies at the institution of higher education correlates with the awareness of the goal $\left(\mathrm{r}_{\mathrm{s}}=0.38, \mathrm{p}=0.02 ; \mathrm{r}_{\mathrm{s}}=0.34, \mathrm{p}=0.03\right.$, respectively), but group A does not display this correlation. Thus, the more a student is aware of his/her goal, the more importance is attached to work as the means for gaining academic success.

Another characteristic were the age groups differ is the evaluation of the role of various connections and friends (F3). The younger respondents (groups A and B) regard it as important for their academic success, the evidence of which is a strong correlation between factor F3 and the ability to select means (A3): $r_{s}=0.45, p=0.01 ; r_{s}=0.36, p=0.04$, respectively. The correlation analysis does not identify this 
correlation for group $\mathrm{C}$, which means that older students regard making contacts and the help of friends as less important for their studies.

Table 2

The comparison of respondents' purposefulness by age groups

\begin{tabular}{|l|c|c|c|c|c|c|c|}
\hline Factor & $\begin{array}{c}\text { Age } \\
\text { group }\end{array}$ & Mean & SD & $\begin{array}{c}\text { Mean } \\
\text { Rank }\end{array}$ & $\begin{array}{c}\text { Chi- } \\
\text { Square }\end{array}$ & df & p \\
\hline \multirow{3}{*}{ A1 } & A & 3.94 & 0.68 & 43.46 & & & \\
& B & 4.29 & 0.62 & 57.00 & 8.55 & 2 & 0.014 \\
\hline \multirow{3}{*}{ A6 } & C & 4.39 & 0.68 & 62.37 & & & \\
& A & 3.63 & 0.94 & 42.97 & & \\
& B & 4.17 & 0.75 & 60.13 & 8.12 & 2 & 0.017 \\
C4 & C & 4.16 & 0.72 & 59.93 & & & \\
& $\mathrm{~A}$ & 3.23 & 1.11 & 44.43 & & & \multirow{2}{*}{0.020} \\
\hline \multirow{3}{*}{ F1 } & $\mathrm{B}$ & 3.66 & 0.68 & 54.33 & 7.83 & 2 & \\
& $\mathrm{C}$ & 3.89 & 1.01 & 63.93 & & & \\
& $\mathrm{~A}$ & 4.37 & 0.69 & 49.86 & & & \\
& $\mathrm{~B}$ & 4.20 & 0.99 & 47.67 & 8.75 & 2 & 0.013 \\
\hline
\end{tabular}

Kruskal Wallis Test was used for the graphic comparison of the age groups. The test shows that there are statistically significant differences between the age groups (Table 2). Higher mean values (M) and higher-ranking values of the responses refer to the respondents with more life experience, which implies a higher level of purposefulness compared to the respondents who have entered the institution of higher education right after finishing secondary school or less than 6 years after that. Chi-Square with the significance level $p=0.013-0.020$ indicates the presence of statistically significant differences between the age groups.

\section{Conclusions}

- Goals are an integral part of the structure of personality direction and one of the sources of motivation, whereas personality direction is the core of personality, but personality needs are a precondition for purposefulness. Purposefulness is an important indicator of teacher's competitiveness, i.e., demandability and employability, as well as the psychological preparedness for independent professional activity, while experience is the basis for competitiveness, including purposefulness. Purposefulness also refers to the precondition and result of continuous education, self-directed learning, life-long professional development and self-determination, as well as career self-direction. Purposefulness as a general psychological personality feature forms and develops in the process of self-regulation and self-actualization of prospective teachers.

- In order to facilitate the formation of purposefulness, it is important to single out and evaluate factors promoting purposefulness: the need to achieve the goal, the awareness of one's goals and setting the goals, the choice of the means to achieve the goals, the ability to use the means appropriate for a particular situation to achieve the goals, making a specific plan for future life activities and the implementation of this plan. It was established in the present study that these skills are not high, but most of the students are aware of the necessity to be purposeful in their activities. Overall, students' answers are neutral because the first-year students are still developing their purposefulness skills.

- Prospective teachers need knowledge how to facilitate the development of purposefulness, the awareness of choosing their life goals and the possibilities of achieving them. The facilitation of purposefulness in the process of studies is one of the key opportunities to develop students' self-regulation skills and promote the development of self-confidence and self-esteem.

- The results obtained in the study show that prospective teachers are responsible and independent; they are aware of the goals of their activities, are able to set them, choose appropriate means for achieving these goals and apply them. 
- The results of both descriptive statistics and statistical conclusions show that not all the respondents see a connection between achieving the goal and knowledge, skills and experience as the means of achieving this goal. The respondents see the role of their individual potentialities and talents only regarding the ability to set the goal, where a weak correlation can be observed.

- There can be singled out slight differences between the views of full-time and part-time students. Due to their little study experience, the students evaluate their academic success cautiously; at the same time, they regard studies at the institution of higher education as very important for their lives.

- The higher mean values and higher-ranking values of responses correspond to the respondents having more life experience, which implies a higher level of purposefulness compared to the respondents who have entered the university right after finishing secondary school or less than 6 years after that. The results of comparative statistics indicate that there are statistically significant differences between the age groups.

- Regarding the facilitation of the development of purposefulness, it is important to highlight the following idea: if prospective teachers understand the studies as the process of activity personally significant for themselves, they are gaining self-experience, where the process of studies is becoming personally significant for them. The data of the study imply that most students do not regard their studies as the process of activity significant for them.

\section{Bibliography}

1. Asonitou S. (2015). Employability Skills in Higher Education and the Case of Greece. Procedia Social and Behavioral Sciences, 175, 283 - 290.

2. Baltusite R. (2013). The Pedagogy Students' Readiness for Professional Activities in the School Environment. The Summary of Doctoral Thesis. Jelgava: Latvia University of Agriculture.

3. Baltusite R., Katane I. (2017). The Modern Teacher's Career. In V. Dislere (Ed.), The Proceedings of the International Scientific Conference Rural Environment. Education. Personality (REEP), 10. Jelgava: LLU TF IMI, 30 - 39. Retrieved from http://lufb.llu.lv/conference/REEP/2017/LatviaUniv-Agricult-REEP-2017_proceedings.pdf

4. Baltusite R., Katane I. (2014). The Structural Model of the Pedagogy Students' Readiness for Professional Activities in the Educational Environment. In V. Dislere (Ed.), The Proceedings of the International Scientific Conference Rural Environment. Education. Personality (REEP),7. Jelgava: LLU TF IMI, 29 - 41. Retrieved from http://lufb.llu.lv/conference/REEP/2014/LatviaUniv-Agricult-REEP-2014proceedings.pdf

5. Bandura A. (1977). Self-efficacy: Toward a unifying theory of behavioral change. Psychological Review, 84 (2), 191-215.

6. Bandura A. (1986). Social Foundations of Thought and Action: A Social Cognitive Theory. Englewood Cliffs, NJ, US: Prentice-Hall, Inc.

7. Bary R., Rees M. (2006). Is (self-directed) learning the key skill for tomorrow's engineers? European Journal of Engineering Education, 31(1), 73-81.

8. Bernande M. (2013). Correlation between Purposefulness and a Development in Life. Synopsis of Ph.D. Thesis. Riga: RPIVA.

9. Bogoyavlenskaya D., Kliueva O. (2013). To the Problem of Competitive Personality Concept. Procedia - Social and Behavioral Sciences, 86, 363-368.

10. Boholano H.B., Abao E.L., Merin J.A., Cardillo M. (2016). Marketability of Filipino Teacher Education Graduates. Journal of Management Science and Business Intelligence, 1(1), 1-11. Retrieved from http://ibii-us.org/Journals/JMSBI/V1N1/Publish/V1N1_1.pdf

11. Brigmane B. (2014). Formation of adults' self-experience through the process of learning. Summary of Doctoral Thesis. Riga: RPIVA

12. Caughlin J. P. (2010). A multiple goals theory of personal relationships: Conceptual integration and program overview. Journal of Social and Personal Relationships, 27 (6), 824-848.

13. Covington M.V. (1992). Making the grade. A Self-Worth Perspective on Motivation and School Reform. New York, NY, US: Cambridge University Press.

14. Education at a Glance 2018: OECD Indicators. (2018). Paris: OECD. Retrieved from http://dx.doi.org/10.1787/eag-2018-en 
15. Gokce F. (2010). Assessment of teacher motivation. School Leadership and Management, 30(5), 487-499.

16. Hirschi A. (2010). Vocational Interests and Career Goals: Development and Relations to Personality in Middle Adolescence. Journal of Career Assessment, 18 (3), 223-238.

17. Iriste S., Katane I. (2016). Experience-Based Learning and Active Learning Environment for Promotion of Prospective Hospitality Business Managers Competitiveness. In V. Dislere (Ed.), The Proceedings of the Scientific International Conference Rural Environment. Education. Personality, (REEP), 9. Jelgava: LLU TF IMI, 17 - 28. Retrieved from http://lufb.llu.lv/conference/REEP/2016/Latvia-Univ-Agricult-REEP-2016proceed2255-808X.pdf

18. Jurgena I., Gedrovics J. (2011). The Views of Senior Form Students Regarding their Future Profession. In V. Lubkina, G. Marinosson (Eds.), The Proceedings of the International Scientific Conference Society, Integration, Education, 2. Rēzekne: RA, 189-199.

19. Jurgena I., Gedrovics J., Cedere D. (2014). Students' views on the professional career opportunities. In A. Aboltins (Ed.), The Proceedings of the International Scientific Conference Engineering for Rural Development, 13. Jelgava: LLU, 522-528. Retrieved from http://www.tf.llu.lv/conference/proceedings2014/Papers/89_Jurgena_I.pdf

20. Kalnina I., Katane I. (2010). Personality Competitiveness: Structure and Indications in Pedagogy. In Proceedings of the Latvia University of Agriculture, 24 (319), 65-75. Retrieved from http://llufb.1lu.lv/proceedings/n24/8/LLU_raksti_Nr24-65-75.pdf

21. Kardeliene L. (2016). Purposefulness of physical education teachers as a determinant of their pupils' objective position in physical education activities in postmodern society. Pedagogika, 124 (4), $206-215$.

22. Katane I. (2010). Competitiveness of Personality as a New Concept in Modern Education and Pedagogy Science. In K. Vartukapteinis (Ed.), The Proceedings of the International Scientific Conference Engineering for Rural Development, 9. Jelgava: LLU, 327 - 334. Retrieved from $\mathrm{http}: / / w w w . t f .11$ u.lv/conference/proceedings2010/Papers/62_Katane_Irena.pdf

23. Katane I. (2011a). Methodological Bases for Evaluation of Specialist Competitiveness. In G. Birzietis (Ed.), The Proceedings of the International Scientific Conference Engineering for Rural Development, 10. Jelgava: LLU, 524 - 529. Retrieved from http://www.tf.1lu.lv/conference/proceedings2011/Papers/097_Katane.pdf

24. Katane I. (2011b). Theoretical Bases for Research of Educators' Competitiveness in Pedagogy Science and Education. In V. Lubkina, G. Marinosson (Eds.), The Proceedings of the International Scientific Conference Society. Integration. Education, 1. Rēzekne: RA, 103-114.

25. Katane I., Baltusite R., Katans E. (2017). Theoretical background for investigation and promotion of engineers' competitiveness in education. In A. Aboltins (Ed.), The Proceedings of the International Scientific Conference Engineering for Rural Development, 16. Jelgava: LLU TF, 824 - 831. Retrieved from http://www.tf.1lu.lv/conference/proceedings2017/Papers/N169.pdf

26. Laing K., Todd L. (Eds.). (2015). Theory-based Methodology: Using theories of change for development, research and evaluation. Newcastle: Newcastle University, Research Centre for Learning and Teaching.

27. Lamanauskas V., Augiene D. (2017). Work values of Lithuanian University Students: Internal structure. Psychological Thought, 10 (1), 109-123.

28. Leontiev A.N. (1978/2000). Activity, Consciousness and Personality. Prentice-Hall. Retrieved from https://www.marxists.org/archive/leontev/works/1978/index.htm

29. Locke E.A., Latham G.P. (1991). A Theory of Goal Setting and Task Performance. The Academy of Management Review, 16 (2), 212 - 247.

30. Maslow A.H. (1954). Motivation and personality. New York: Harper and Row.

31. May R. (1989). Love and will. New York, London: W.W. Norton and Company.

32. Meissner W.W. (2009). Volition and Will in Psychoanalysis. Journal of the American Psychoanalytic, 57(5), 1123-1156.

33. National Reform Programme of Latvia. (2018). Europe 2020 Strategy. Retrieved from: https://www.em.gov.lv/en/latvia_in_the_eu/europe_2020_strategy/national_reform_programme_of_latvia/

34. Nuttin J., Lens W. (Eds.). (1984). Future time perspective and motivation: theory and research method. Leuven: Leuven University Press. 
35. Paradnike K., Endriulaitiene A., Bandzeviciene R. (2016). Career self-management resources in contemporary career frameworks: a literature review. Management of Organizations: Systematic Research, 76, $91-106$.

36. Rubinstein S.L. (1989/2004). Osnovi obshchei psihologii (Fundamentals of General Psychology). Sankt-Peterburg: Piter. (in Russian)

37. Schunk D.H., Pajares F. (2009). Self-efficacy theory. In K.R. Wentzel, A. Wigfield (Eds.), Educational psychology handbook series. Handbook of motivation at school. New York, NY, US: Routledge/Taylor \& Francis Group, 35-53.

38. Shirobokov S.N., Roe R.C. (2005). Training Marketable and Effective Professionals: Assessing Student Learning Outcomes and Its Relevance to the International Labor Market. Omsk: Omsk State Pedagogical University.

39. Statistika par augstako izglitibu (Statistics on Higher Education). (2018). Riga: IZM. Retrieved from http://www.izm.gov.lv/lv/publikacijas-un-statistika/statistika-par-izglitibu/statistika-paraugstako-izglitibu (in Latvian)

40. Strode A. (2010). Students' Independent Professional Activity in Pedagogical Practice. Summary of Doctoral Thesis. Daugavpils: DU.

41. Strods G. (2006). Educational aspects of students' self-directed learning. In V. Lubkina (Ed.), The Proceedings of the International Scientific Conference Society. Integration. Education. Rezekne: RA, 93-105.

42. Strods G. (2012). Promotion of Students' Self-determination in Cooperative Learning Process at University. Summary of Doctoral Thesis. Riga: LU.

43. Sustainable Development Strategy of Latvia until 2030 (2010). Riga: Saeima of the Republic of Latvia. Retrieved from http://www.pkc.gov.lv/sites/default/files/imageslegacy/LV2030/LIAS_2030_en.pdf

44. Vallerand R.J. (1997). Toward a Hierarchical model of Intrinsic and Extrinsic Motivation. In M.P. Zanna (Ed.), Advances in experimental social psychology. New York: Academic Press, 29, 271-360.

45. Walsh J.A., Sattes B.D. (2016). Quality questioning: Research-based practice to engage every learner. Thousand Oaks, CA: Corwin Press.

46. Wang Z., Utemov V.V., Krivonozhkina E.K., Liu G., Galushkin A.A. (2018). Pedagogical Readiness of Mathematics Teachers to Implement Innovative Forms of Educational Activities. Eurasia Journal of Mathematics, Science and Technology Education, 14(1), 543-552.

47. Weiner B. (1996). An attributional theory of motivation and emotion. New York: Springer Verlag.

48. Weiner B. (2000). Intrapersonal and Interpersonal Theories of Motivation from an Attributional Perspective. Educational Psychology Review, 12(1), 1-14

49. White R.W. (1959). Motivation reconsidered. The concept of competence. Psychological Review, 66(5), 297-333.

50. Winch Ch., Foreman-Peck L. (2000). Teacher professionalism, educational aims and action research: the evolution of policy in the United Kingdom. Teacher Development, 4 (2), 165-176.

51. Yeager D.S., Bundick M.J. (2009). The Role of Purposeful Work Goals in Promoting Meaning in Life and in Schoolwork during Adolescence. Journal of Adolescent Research, 24 (4), 423-452. 